\title{
NUMERICAL SIMULATION AND EXPERIMENTAL VERIFICATION OF THE QUENCHING TEMPERATURE FIELD OF GRINDING BALLS
}

\author{
NUMERIČNA SIMULACIJA IN EKSPERIMENTALNA \\ VERIFIKACIJA TEMPERATURNEGA POLJA KALJENJA \\ MLEVSKIH KROGEL
}

\author{
Mengchao Song, Yisong Pu, Qi Liu, Ran Wang, Baoqi Wang* \\ School of Materials Science and Engineering, Hebei University of Technology, No. 8 Dingziguyihao Road, Hongqiao District, Tianjin 300130, \\ China
}

Prejem rokopisa - received: 2018-10-21; sprejem za objavo - accepted for publication: 2019-01-30

doi:10.17222/mit.2018.226

\begin{abstract}
A mathematical model for the quenching heat transfer of grinding balls was established based on the heat-conduction equation and the law of conservation of energy. The heat-conduction equation was differentiated with the finite-difference method and the boundary conditions were solved based on the volumetric method. The numerical simulation of the quenching temperature field was carried out using the MATLAB software programming. The hardness and microstructure of a grinding ball after the heat treatment were analyzed by means of a Rockwell hardness tester, OM and SEM, which were also used to verify the correctness of the simulation data. The results show that the simulation data for the quenching temperature field at a water temperature of $35^{\circ} \mathrm{C}$ were in good agreement with the experimental results obtained with water quenching at temperatures of $34-36^{\circ} \mathrm{C}$. The hardness range for a grinding ball from the surface to the center was 59.4-57.9 HRC. The grinding ball was completely hardened and the overall martensite structure could be obtained.
\end{abstract}

Keywords: grinding balls, quenching temperature field, numerical simulation, cooling curve

Avtorji so izdelali matematični model za prenos toplote med kaljenjem mlevskih krogel, ki temelji na enačbah za prevajanje toplote in na zakonu o ohranitvi energije. Enačba za prevajanje toplote je bila pri izbranih robnih pogojih matematično odvajana $\mathrm{z}$ metodo končnih diferenc. Njena rešitev je temeljila na volumetrični metodi. Numerično simulacijo temperaturnega polja kaljenja so izvajali s pomočjo MATLAB programske opreme. Trdoto kaljenih mlevskih krogel so določili z Rockwellovim merilnikom trdote, njihovo mikrostrukturo pa so opazovali pod optičnim (OM) in vrstičnim elektronskim mikroskopom (SEM). Dobljene podatke oz. rezultate so uporabili za verifikacijo modela. Rezultati analize so pokazali, da se rezultati simulacije temperaturnega polja kaljenja pri temperaturi vode $35^{\circ} \mathrm{C}$ dobro ujemajo z eksperimentalnimi rezultati, izvedenimi pri temperaturi vode $34{ }^{\circ} \mathrm{C}$ do $36^{\circ} \mathrm{C}$. Trdota mlevskih krogel se je gibala od površine proti sredini od 59,4 HRC do 57,9 HRC. Po kaljenju so bile krogle popolnoma prekaljene in so imele po preseku v celoti martenzitno mikrostrukturo.

Ključne besede: krogle za mletje, temperaturno polje kaljenja, numerična simulacija, ohlajevalna krivulja

\section{INTRODUCTION}

Quenching, as an effective process to improve performance, is widely applied in the processing of grinding balls. ${ }^{1-3}$ In this process, quenching is complicated due to the interaction of its temperature, microstructure and stress-strain fields. ${ }^{4-6}$ Temperature changes cannot be observed and measured directly during the quenching process of a grinding ball, which affects the improvement of the quality and seriously restricts the formulation of the quenching process. ${ }^{7-8}$ Hence, it is difficult for the materials to exert their optimum performance.

The establishment of a mathematical model of heat treatment and the accuracy of physical parameters are critical for the simulation results. The model provides a theoretical basis for the simulation of the temperature field of a quenching process. ${ }^{9-10}$ The quenching process can be objectively analyzed based on a computer nume-

*Corresponding author's e-mail:

baoqiwang6020@163.com (Baoqi Wang) rical simulation before the experiment to reduce the research cycle of the quenching process and provide a scientific basis for the formulation of the heat-treatment process. ${ }^{11-16}$

In this paper, a heat-transfer model of a quenching process is established based on the Fourier heat-conduction equation and the law of conservation of energy; and the finite-difference method is used to solve the nonlinear heat-conduction equation. Besides, the quenching temperature field is numerically calculated using the MATLAB software to predict the temperature variation and cooling rate.

\section{EXPERIMENTAL PART}

\subsection{Experimental materials and methods}

The experimental steel was a high-quality steel for $\phi 125 \mathrm{~mm}$ forged grinding balls. The chemical composition was $0.69 \mathrm{C}-0.8 \mathrm{Si}-0.98 \mathrm{Mn}-0.76 \mathrm{Cr}-0.02 \mathrm{Ni}-$ $0.007 \mathrm{Mo}-0.05 \mathrm{Al}-0.006 \mathrm{~S}-0.02 \mathrm{P}$ (in $w / \%$ ). The critical 
Table 1: Heat treatment of grinding balls

\begin{tabular}{|c|c|c|c|c|c|c|c|c|c|}
\hline $\mathrm{HT}$ & $\mathrm{Ht}$ & IFT & FFT & QT & Wct & WT & MRT & $\mathrm{TT}$ & $\mathrm{Tt}$ \\
\hline $1250{ }^{\circ} \mathrm{C}$ & $2 \mathrm{~h}$ & $980{ }^{\circ} \mathrm{C}$ & $950{ }^{\circ} \mathrm{C}$ & $800^{\circ} \mathrm{C}$ & $180 \mathrm{~s}$ & $34-36{ }^{\circ} \mathrm{C}$ & $155^{\circ} \mathrm{C}$ & $200{ }^{\circ} \mathrm{C}$ & $4 \mathrm{~h}$ \\
\hline
\end{tabular}

HT: heating temperature, Ht: heating time, IFT: initial forging temperature, FFT: final forging temperature, QT: quenching temperature, Wct: water cooling time, WT: water temperature, MRT: maximum return temperature, TT: tempering temperature, Tt: tempering time

temperatures $\mathrm{Ac}_{1}, \mathrm{Ac}_{3}$ and $\mathrm{Ms}$ were measured to be (719, 739 and 254) ${ }^{\circ} \mathrm{C}$, respectively. Figure 1 shows the manufacturing of $\phi 125 \mathrm{~mm}$ grinding balls. Table 1 shows the heat treatment of the grinding balls.

The surface temperature of a grinding ball was measured with an HDR-3 infrared thermometer. The grinding ball was cut into a semi-circular piece with a thickness of $11 \mathrm{~mm}$ with a wire-cut electrical discharge machine; then the two cutting planes were ground. The hardness values were measured every $5 \mathrm{~mm}$ from the surface to the center using a Rockwell hardness tester. After the sample was polished and etched in a solution of $4 \%$ nitric acid in ethanol, the microstructure was observed with optical microscopy (OM) and a Quanta FEG scanning electron microscope (SEM).

\subsection{Simulation of the quenching temperature field}

The temperature field was a function of the temperature, varying with time in a three-dimensional space coordinate system. When calculating the martensite transformation, this study treated latent heat as a form of temperature rise rather than an internal heat source. ${ }^{17,18}$ For an unsteady heat-conduction equation without an internal heat source, Equation (1) can be expressed in a rectangular Cartesian coordinate system due to the fact that the thermal conductivity is the same in the $x, y$ and $z$ directions:

$$
\lambda\left(\frac{\partial^{2} T}{\partial x^{2}}+\frac{\partial^{2} T}{\partial y^{2}}+\frac{\partial^{2} T}{\partial z^{2}}\right)=\rho C_{\mathrm{p}} \frac{\partial T}{\partial t}
$$

where $T$ is the temperature, ${ }^{\circ} \mathrm{C} ; \lambda$ is the thermal conductivity, $\mathrm{W} /\left(\mathrm{m} \cdot{ }^{\circ} \mathrm{C}\right) ; \rho$ is the density, $\mathrm{kg} / ; \mathrm{C}_{\mathrm{p}}$ is the specific heat capacity, $\mathrm{J} /\left(\mathrm{kg} \cdot{ }^{\circ} \mathrm{C}\right)$; and $t$ is the time, s.

In this study, we calculated the distribution of the temperature field in a spherical coordinate system based on the simple geometry shown in Figure 2. Equation (1) can be rewritten as Equation (2) for the spherical coordinate system:

$$
\frac{\partial^{2} T}{\partial r^{2}}+\frac{1}{2} \frac{\partial T}{\partial r}+\frac{1}{r \sin \varphi} \frac{\partial}{\partial \varphi}\left(\frac{\partial T}{\partial \varphi}\right)+\frac{1}{r^{2} \sin ^{2} \varphi} \frac{\partial^{2} T}{\partial \phi^{2}}=\frac{1}{\alpha} \frac{\partial T}{\partial t}(2)
$$

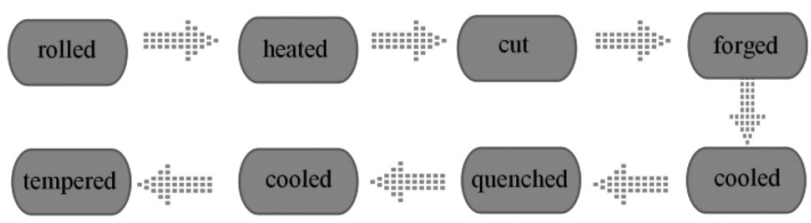

Figure 1: Manufacturing of $\phi 125 \mathrm{~mm}$ grinding balls
Where $\mathrm{a}=1 /\left(\rho \cdot C_{\mathrm{p}}\right)$ and $\alpha$ is the thermal diffusivity, $\mathrm{m}^{2} / \mathrm{s} ; r, \varphi$ and $\psi$ are the radial distance, the azimuth angle and the zenith angle, respectively.

The quenching temperature field followed the geometric symmetry distribution due to a higher symmetry of the grinding ball. There was no heat transfer in the directions of $\varphi$ and $\psi$ in the heat-transfer process inside the grinding ball. Thus, Equation (2) can be further simplified as follows:

$$
\frac{\partial^{2} T}{\partial r^{2}}+\frac{2}{r} \frac{\partial T}{\partial r}=\frac{1}{\alpha} \frac{\partial T}{\partial t}
$$

The heat-conduction equation shows that the heat transfer was only one-dimensional, in the radial $r$ direction. Therefore, the space variable $r$ and the time variable $t$ were discretized in the process of solving the heat-conduction equation, which can be expressed as follows:

$$
\begin{gathered}
r=(j-1) \cdot r \quad j=1,2,3 \ldots N+1 \\
t=n \cdot t \quad n=1,2,3 \ldots
\end{gathered}
$$

Then $T(r, t)$ can be expressed as:

$$
T(r, t)=T[(j-1) \cdot r, t=n \cdot t]=T_{j}^{n}
$$

The finite-difference method was used to replace the temperature field as shown in Equations (7)-(8).

$$
\begin{aligned}
\frac{\partial T}{\partial r} & =\frac{T_{j+1}^{n+1}-T_{j}^{n+1}}{\partial r} \\
\frac{\partial T}{\partial t} & =\frac{T_{j}^{n+1}-T_{j}^{n}}{\partial t}
\end{aligned}
$$

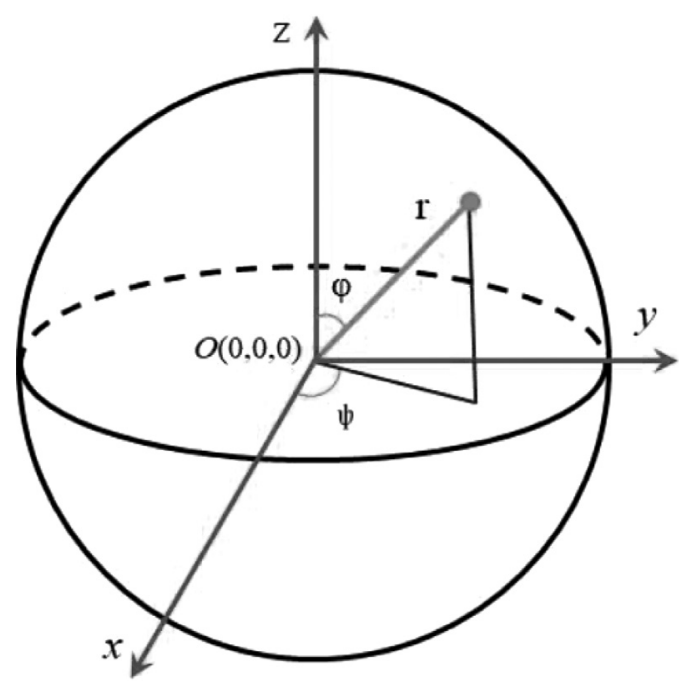

Figure 2: Spherical coordinate system of a grinding ball 

into:

Therefore, Equation (3) can be further simplified

$$
\begin{aligned}
& -T_{j-1}^{n+1}+\left(2+\frac{2}{j-1}+u\right) T_{j}^{n+1}- \\
& -\left(1-\frac{2}{j-1}\right) T_{j+1}^{n+1}=u\left(2+\frac{2}{j-1}+u\right) T_{j}^{n}
\end{aligned}
$$

Where $u=\left(r \cdot C_{\mathrm{p}} / \lambda\right) \cdot\left(\Delta r^{2} / \Delta t\right) ; j=2,3,4 \ldots$, superscript $n+1$ and $n$ represent the time of $n+1$ and $n$, respectively; $j=1$ and $j=N+1$ represent the center and surface node, respectively. When the grinding ball was forged, the difference in the temperature between the surface and the center was small enough to be considered negligible, and the initial temperature of the grinding ball was homogenized: $T_{j}^{0}=T_{0}$.

The point-centered method based on the volumetric method was used to determine the grinding-ball node as shown in Figure 3. The calculation area was divided into a finite number of grids using the interface line. The node was located at the corner of the grid, and its value was the average of the volume. The node of the point angle was calculated based on 1/4 of the control volume, and the other nodes on the boundary were calculated based on $1 / 2$ of the control volume. ${ }^{19}$

There was no temperature transfer on the sphere of the same radius. The radius and the sphere of the ball can be divided into $N$ and $m$ equal parts, respectively. If the center of the sphere is regarded as the origin of the coordinate axis, the points on the sphere can be expressed with $j=N+1$ in a one-dimensional coordinate system. According to the law of conservation of energy, the heat transferred from the coordinate $j=N$ to the position $j=N+1$ is $Q_{1}$, the coordinate $j=N+1$ is $Q_{2}$, and the coordinate $j=N+1$ is $Q_{3}$.

$$
Q_{3}=Q_{1}-Q_{2}
$$

The above Equation can be simplified:

$$
Q_{1}=\lambda\left(\frac{T_{N}^{n}-T_{N+1}^{n}}{\Delta r}\right) \frac{4 \pi\left(r_{0}-\frac{\Delta r}{2}\right)^{2}}{m}
$$

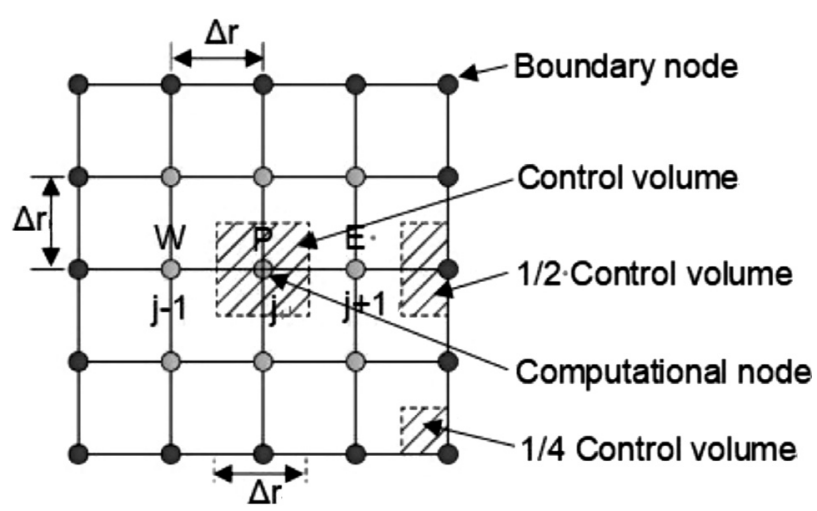

Figure 3: Figure of the finite-volume method for regional discretization

$$
\begin{gathered}
Q_{2}=U\left(T_{N+1}^{n}-T_{f}\right) \cdot \frac{4 \pi r^{2}}{m} \\
U=\frac{h_{1} \cdot h_{2}}{h_{1}+h_{2}}
\end{gathered}
$$

where $U$ is the overall heat-transfer coefficient of the quenching medium, $\mathrm{W} /\left(\mathrm{m}^{2} \cdot{ }^{\circ} \mathrm{C}\right) ; h_{1}$ is the heat-transfer coefficient of air; $h_{2}$ is the heat-transfer coefficient of water; $T_{\mathrm{f}}$ is the temperature of the quenching medium; $T_{N+1}^{n}$ and $T_{N+1}^{n+1}$ are the surface-temperature values at the time of $\mathrm{n}$ and $\mathrm{n}+1$, respectively.

$$
Q_{3}=\rho C_{\mathrm{p}} \frac{\frac{4}{3} \pi\left[r^{3}-\left(r_{0}-\frac{\Delta r}{2}\right)^{3}\right]}{m} \cdot \frac{T_{N+1}^{n+1}-T_{N+1}^{n}}{\Delta t}
$$

Equation merging was obtained as follows:

$$
\begin{aligned}
& \lambda\left(\frac{T_{N}^{n}-T_{N+1}^{n}}{\Delta r}\right)\left(N-\frac{1}{2}\right)^{2}-U\left(T_{N+1}^{n}-T_{\mathrm{f}}\right) N^{2}= \\
& =\rho C_{\mathrm{p}} \frac{N^{3}-\left(N-\frac{1}{2}\right)^{3}}{3} \frac{\Delta r}{\Delta t}\left(T_{N+1}^{n+1}-T_{N+1}^{n}\right)
\end{aligned}
$$

Therefore, the temperature of $T_{N}^{n}$ and $T_{N+1}^{n}$ at time $n$ could be used to calculate the temperature of $T_{N+1}^{n+1}$ at time $n+1$.

The center position $j=1$ was only heated radially to its adjacent point, causing its own temperature change. The heat transferred from node 1 to node 2 per unit time was calculated as $Q$, and the heat change at node 1 was $R$, thus, the following Equations could be obtained:

$$
\begin{gathered}
Q=\lambda \frac{T_{1}^{n+1}-T_{2}^{n+1}}{\Delta r} \frac{\pi(\Delta r)^{2}}{m} \\
R=\rho C_{\mathrm{p}} \frac{\frac{1}{6} \pi(\Delta r)^{3}}{m} \frac{T_{1}^{n+1}-T_{1}^{n}}{\Delta t} \\
T_{1}^{n+1}-T_{2}^{n+1}=\frac{\rho C_{\mathrm{p}}}{\lambda} \frac{1}{6}(\Delta r)^{2} \frac{T_{1}^{n}-T_{1}^{n+1}}{\Delta t}
\end{gathered}
$$

The temperature of the center node $j=1$ could be solved with Equations (9) and (18), and the chasing method could be used to obtain the expression $T_{N}^{n+1}$. According to the initial conditions, boundary conditions and heat-conduction equations, the temperature change at each node at any time could be obtained. Combined with the MATLAB software programming, the quenching temperature field was calculated.

\section{RESULTS AND DISCUSSION}

In the quenching temperature field of the $\phi 125 \mathrm{~mm}$ grinding ball, the density of steel was $7833 \mathrm{~kg} / \mathrm{m}^{3}$ and the air temperature was $30^{\circ} \mathrm{C}$. The literature shows that the heat-transfer coefficient $h_{1}$ relates to air and the heat-transfer coefficient $h_{2}$ relates to water. ${ }^{20}$ The litera- 
ture also describes the thermal conductivity and specific heat capacity. ${ }^{21}$

To obtain a high hardness, the cooling rate at each position was higher than that of the martensitic transformation. The average cooling rate was calculated with Equation (19):

$$
v=\frac{800-300}{\sum \Delta t}
$$

where $v$ is the average cooling rate of undercooling the austenite in the temperature range of $800-300{ }^{\circ} \mathrm{C}$, and $\sum \Delta t$ is the cooling time taken between $800{ }^{\circ} \mathrm{C}$ and $300{ }^{\circ} \mathrm{C}$.

Figure 4 shows the simulation results of the temperature field during the quenching process. As shown in Figure 4a, the surface was air cooled from $950{ }^{\circ} \mathrm{C}$ to 800 ${ }^{\circ} \mathrm{C}$, and this process took $125 \mathrm{~s}$. At this point, the heat at the center was $884{ }^{\circ} \mathrm{C}$, and the temperature difference between the surface and the center was $84{ }^{\circ} \mathrm{C}$. Then, the center was water cooled to $300{ }^{\circ} \mathrm{C}$, and this process took $180 \mathrm{~s}$. At this time, the surface heat was $96^{\circ} \mathrm{C}$, and the temperature difference between the surface and the center was $204{ }^{\circ} \mathrm{C}$. When the heat at the center was $300{ }^{\circ} \mathrm{C}$, the grinding ball left the water. At this moment, the tem-
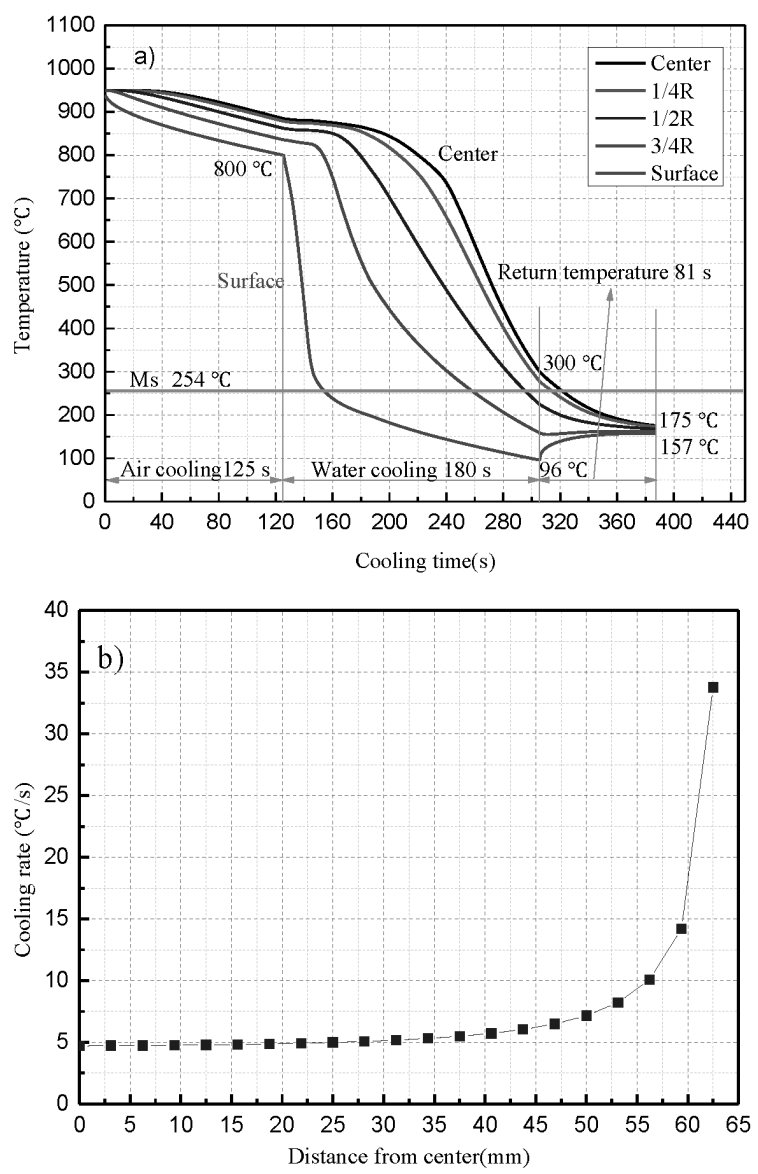

Figure 4: Simulation of the quenching temperature field for a grinding ball: a) temperature-change curve for the grinding ball; b) average cooling rate during $800-300{ }^{\circ} \mathrm{C}$ perature in the range from the surface to $1 / 2 \mathrm{R}$ dropped below Ms. When leaving the water for $16 \mathrm{~s}$, the temperature of the whole ball dropped below Ms. When leaving the water for $81 \mathrm{~s}$, the return temperature of the surface reached the maximum temperature of $157^{\circ} \mathrm{C}$. If the return temperature of the surface reaches its maximum after leaving the water, the calculation is finished. The maximum return temperature in the process of the actual measurement was $155^{\circ} \mathrm{C}$, which was similar to the simulated data.

Figure $4 \mathbf{b}$ shows that the minimum cooling rate at the center was $4.7{ }^{\circ} \mathrm{C} / \mathrm{s}$. The critical cooling rate for the martensite formation was actually calculated to be $4.5^{\circ} \mathrm{C} / \mathrm{s}$. Thus, the average cooling rate from the surface to the center was higher than the critical cooling rate for the martensite formation. We predicted that the grinding balls could be completely hardened under the temperature field and the overall martensite structure could be obtained.

Figure 5 shows the calculation results of the martensite transformation at different positions when leaving the water, which was after 305 s. The amount of martensite was a function of the temperature and could be calculated with Equation (20). ${ }^{22}$ After leaving the water, martensite was found $30 \mathrm{~mm}$ from the center. The amount of martensite was up to $80 \%$ at the surface, and the conversion degree exceeded $50 \%$ in the $20-\mathrm{mm}$ surface layer. When leaving the water for $21 \mathrm{~s}$, martensite was found at the center. With the decrease in the temperature difference between the surface and the center, much martensite transformed simultaneously, and the properties of the grinding ball became more stable.

$$
f=1-\exp [-0.011(M s-T)]
$$

Here, $M s$ is the martensite start temperature.

The grinding ball was cut into a semi-circular piece with a thickness of $11 \mathrm{~mm}$ along the diameter direction. The hardness was measured every $5 \mathrm{~mm}$ from the center to the surface using a digital Rockwell hardness tester

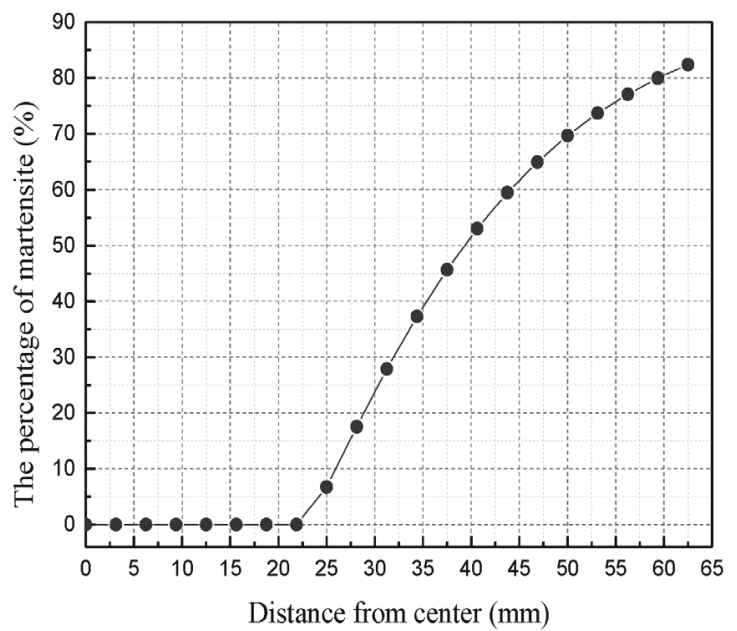

Figure 5: Distribution of the martensite amount within a grinding ball after water quenching 


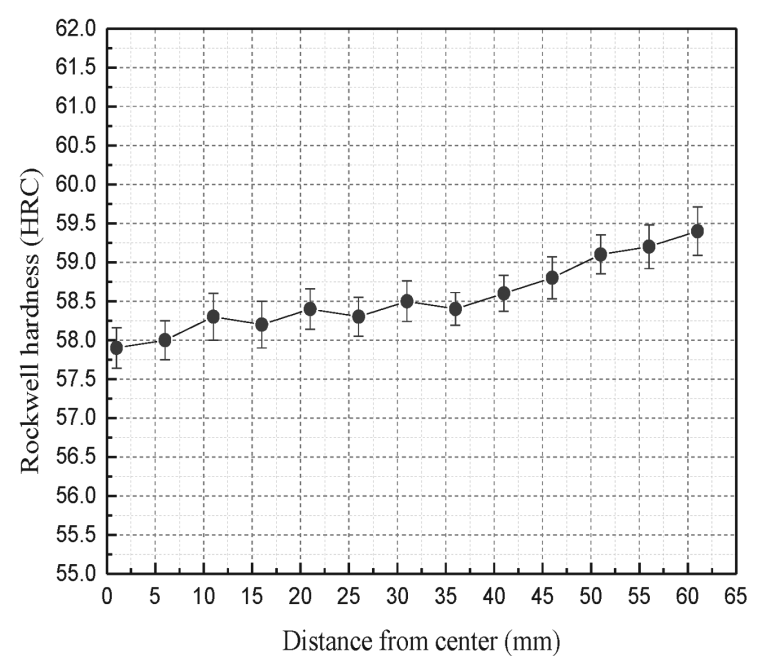

Figure 6: Hardness-distribution curves of the grinding ball. The error bars represent the standard deviation of the measurements for six separate samples.
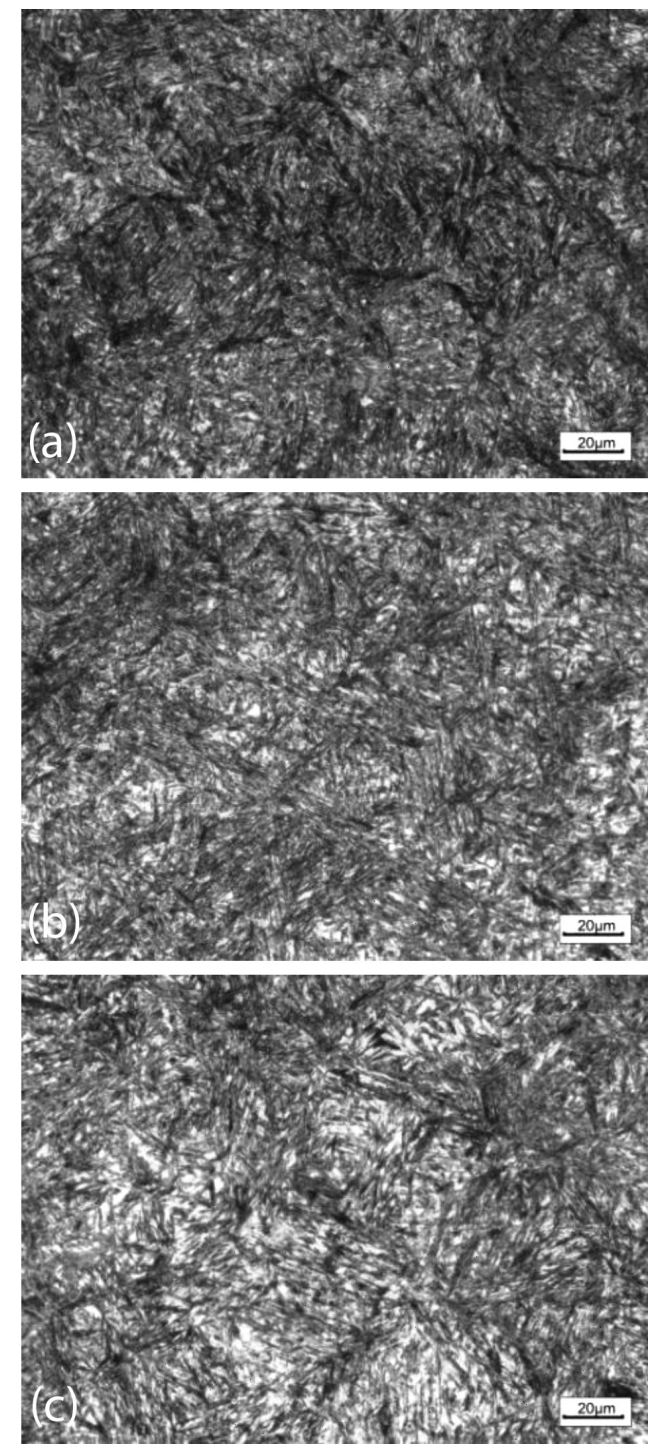

Figure 7: OM images of the grinding ball: a) surface, b) $1 / 2 \mathrm{R}, \mathrm{c}$ ) center
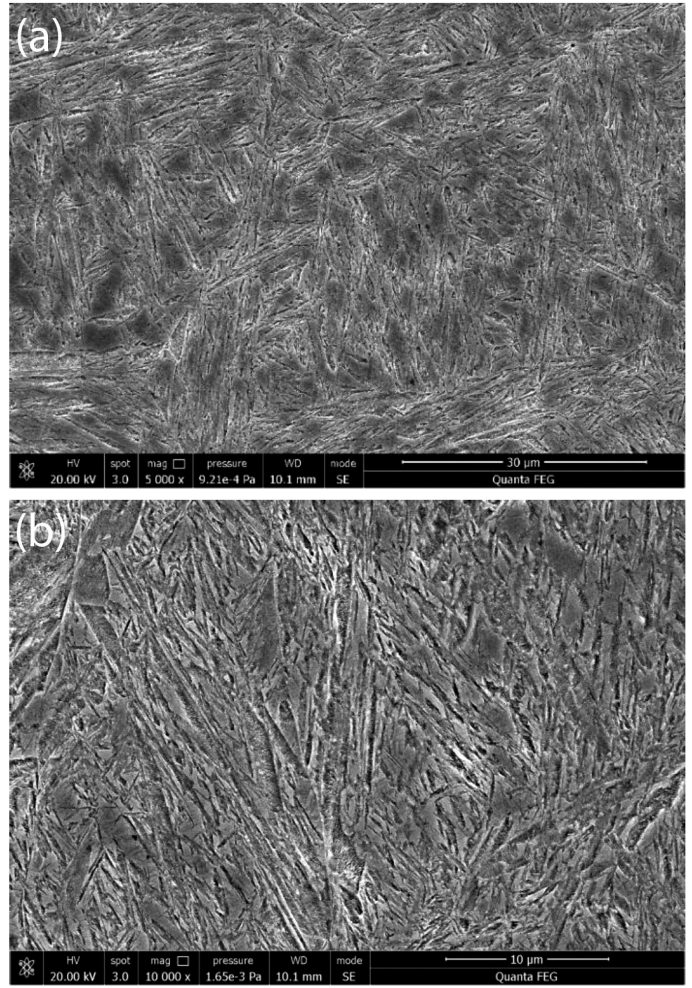

Figure 8: SEM images of the center of the grinding ball: a) low magnification, b) high magnification

with an accuracy of 0.1 HRC. Every hardness value was measured six times and averaged, and the hardness distribution is shown in Figure 6. With the increase in the distance from the surface, the hardness decreased smoothly. The hardness range of the grinding ball from the surface to the center was 59.4-57.9 HRC, and the hardness almost had a homogeneous distribution. In terms of hardness distribution, the grinding ball was completely hardened, indicating that the simulation results were accurate.

Figure 7 shows the microstructures of the surface, $1 / 2 \mathrm{R}$ and the center obtained with OM. The distribution of the martensite from the surface to the center was uniform, and there was no preferred orientation. The amount of martensite increased at $1 / 2 \mathrm{R}$, and a small amount of retained austenite appeared. The center structure was composed of martensite and a small amount of retained austenite. The morphology of the center structure can also be seen in Figure 8. The center structure was mainly composed of martensite. The grinding ball could be completely hardened and the simulation results were proved correct again.

The analysis of the above data shows that the results for the grinding balls were consistent with the simulation data of the temperature field, which could provide accurate parameters for the quenching process. According to the requirements of the grinding-ball diameter and quenching temperature, the temperature field could be numerically simulated using the MATLAB software. The simulation results could be used to predict the grind- 
ing-ball structure and performance, improve research efficiency and reduce production costs.

\section{CONCLUSIONS}

The mathematical model for the quenching heat transfer of a grinding ball was established based on the heat-conduction equation and the law of conservation of energy. The quenching temperature field for a $\phi 125-\mathrm{mm}$ grinding ball at a water temperature of $35{ }^{\circ} \mathrm{C}$ was modeled using the MATLAB software.

The surface of the grinding ball was air cooled from $950{ }^{\circ} \mathrm{C}$ to $800{ }^{\circ} \mathrm{C}$, and this process took $125 \mathrm{~s}$. When water-cooled, the center dropped to $300{ }^{\circ} \mathrm{C}$ and this process took $180 \mathrm{~s}$. The cooling rate of the center was $4.7{ }^{\circ} \mathrm{C} / \mathrm{s}$. After leaving the water for $81 \mathrm{~s}$, the return temperature of the surface reached its maximum value of $157^{\circ} \mathrm{C}$. The grinding ball was predicted to be completely hardened.

The $\phi 125-\mathrm{mm}$ grinding ball was water quenched at $34-36{ }^{\circ} \mathrm{C}$ to verify the correctness of the simulation data. The critical cooling rate of the martensite formation was $4.5^{\circ} \mathrm{C} / \mathrm{s}$ and the microstructure was mainly composed of martensite. The hardness range of the grinding ball from the surface to the center was 59.4-57.9 HRC and the hardness almost had a homogeneous distribution. The grinding ball could be completely hardened and the experimental results were consistent with the simulated data.

\section{Conflicts of interest}

The authors declare that they have no conflicts of interest.

\section{Acknowledgments}

The work was financially supported by the Handan City Science and Technology Plan Project (no. 1715104027).

\section{REFERENCES}

${ }^{1}$ T. Sun, R. Song, X. Wang, Microstructure and phase transformation of wear resistant ductile iron grinding balls by continuous cooling process, Materials Science and Engineering A, 626 (2015), 375-381, doi:10.1016/j.msea.2014.12.078

${ }^{2}$ H. Guler, R. Ertan, R. Ozcan, Effect of heat treatment on the microstructure and mechanical properties of $30 \mathrm{MnB} 5$ boron steel, Mater. Tehnol., 48 (2014) 6, 971-976, doi:10.17222/mit.2017.195

${ }^{3}$ A. Sabih, P. Radziszewski, I. Mullany, Investigating grinding media differences in microstructure, hardness, abrasion and fracture toughness, Minerals Engineering, 103 (2016), 43-53, doi:10.1016/ j.mineng.2016.08.014

${ }^{4}$ J. Hrabovsky, M. Pohanka, P. J. Lee, J. H. Kang, Experimental and numerical study of hot-steel-plate flatness, Mater. Tehnol., 50 (2016) 1, 17-21, doi:10.17222/mit.2014.153
${ }^{5}$ Y. J. Li, D Liu, W. N. Zhang, J. Kang, Quenching above martensite start temperature in quenching and partitioning $(\mathrm{Q} \& \mathrm{P})$ steel through control of partial phase transformation, Materials Letters, 230 (2018), 36-39, doi:10.1016/j.matlet.2018.07.062

${ }^{6}$ J. Mackerle, Finite element analysis and simulation of quenching and other heat treatment processes, Computational Materials Science, 27 (2003) 3, 313-332, doi:10.1016/S0927-0256(03)00038-7

${ }^{7}$ P. Carlone, G. S. Palazzo, R. Pasquino, Finite element analysis of the steel quenching process: Temperature field and solid-solid phase change, Computers and Mathematics with Applications, 59 (2000) 1, 585-594, doi:10.1016/j.camwa.2009.06.006

${ }^{8}$ O. Zapata-Hernández, L. A. Reyes, C. Camurri, Quenching simulation of steel grinding balls, Revista De Metalurgia, 51 (2015) 3, 1-6, doi:10.3989/revmetalm.049

${ }^{9}$ L. Malecek, M. Fedorko, F. Vancura, H. Jirkova, B. Masek, Development of numerical models for the heat-treatment-process optimisation in a closed-die forging production, Mater. Tehnol., 49 (2015) 3, 471-475, doi:10.17222/mit.2014.196

${ }^{10}$ C. Camurri, C. Carrasco, J. Dille, Residual stress during heat treatment of steel grinding balls, Journal of Materials Processing Tech., 208 (2008) 1, 450-456, doi:10.1016/j.jmatprotec.2008.01.007

${ }^{11}$ F. Kavicacka, K. Stransky, J. Dobrovska, Numerical and experimental investigation of the temperature field of a solidifying massive ductile-cast-iron roller, Mater. Tehnol., 45 (2012) 4, 321-324

${ }^{12} \mathrm{X}$. Deng, D. Ju, Modeling and simulation of quenching and tempering process in steels, Physics Procedia, 50 (2013), 368-374, doi:10.1016/j.phpro.2013.11.057

${ }^{13}$ G. Y. Liu, D. M. Zhu, S. J. Zhang, Numerical simulation and experiment on quenching process of 718 mould steel with new online hardening equipment, Advanced Materials Research, 307 (2013), 415-420, doi:10.4028/AMR.572.237

${ }^{14}$ M. Jung, S. J. Lee, W. B. Lee, K. I. Moon, Finite element simulation and optimization of gas-quenching process for tool steels, Journal of Materials Engineering and Performance, 27 (2018) 8, 4355-4363, doi:10.1007/s11665-018-3492-6

${ }^{15}$ F. Moukalled, L. Mangani, M. Darwish, General fully implicit discretization of the diffusion term for the finite volume method, Numerical Heat Transfer, Part B: Fundamentals, 71 (2017) 6, 506-532, doi:10.1080/10407790.2017.1330060

${ }^{16}$ H. X. Yang, L. Q. Ren, Inverse heat conduction analysis of quenching process based on finite element method and genetic algorithm, Computational and Theoretical Nanoscience, 5 (2008) 8, doi:10.1166/jctn.2008.858

${ }^{17}$ L. W. Zhang, Z. G. Zhao, Q. L. Fan, Calculation of the temperature field of 35CrMo steel large forging quenching process using finite element method, Heat Treatment of Metals, 12 (1994), 24-27, doif $£^{\circ} 10.13251 /$ j.issn.0254-6051.1994.12.008

${ }^{18}$ S. T. Rui, G. L. Zhang, Numerical simulation of air cooling process after normalizing of large cross-section rotor forging, Heavy Casting and Forging, 4 (2011), 5-7, doi:10.14147/j.cnki.51-1396/tg.2011. 04.001

${ }^{19}$ J. C. Chai, H. O. S. Lee, S. V. Patankar, Finite volume method for radiation heat transfer, Journal of Thermophysics and Heat Transfer, 8 (1994) 3, 419-425, doi:10.2514/3.559

${ }^{20}$ J. Yuan, W. M. Zhang, Z. C. Liu, The measurement and calculation of heat transfer coefficient under different cooling conditions, Transactions of Materials and Heat Treatment, 26 (2005) 4, 115-119, doi:10.13289/j.issn.1009-6264.2005.04.028

${ }^{21}$ Z. Tan, G. W. Guo, Thermophysical properties of engineering alloys, Metallurgical Industry Press, 1 (1994), 14-21

${ }^{22}$ D. P. Koistinen, R. E. Marburger, A general equation prescribing the extent of the austenite-martensite transformation in pure iron-carbon alloys and plain carbon steels, Acta Metallurgica, 7 (1959) 1, 59-60, doi:10.1016/0001-6160(59)90170-1 